\title{
Fluorouracil Continuous Infusion Regimen
}

National Cancer Institute

\section{Source}

National Cancer Institute. Fluorouracil Continuous Infusion Regimen. NCI Thesaurus.

Code C160037.

A chemotherapy regimen consisting of continuous infusion fluorouracil that may be used

in the treatment of esophageal and esophagog astric junction, and gastric cancers; and pancreatic adenocarcinoma. 